\title{
Effects of extensive system versus semi-intensive and intensive systems on growth and carcass quality of dairy kids ${ }^{1}$
}

\section{Pedro Zurita Herrera ${ }^{2}$, Juan Vicente Delgado Bermejo², Anastasio Argüello Henríquez ${ }^{3}$, María Esperanza Camacho Vallejo ${ }^{4}$, Roberto Germano Costa ${ }^{5}$}

\author{
1 Diputación de Granada. \\ 2 Department of Genetic, Córdoba University, 14014 Córdoba, Spain. \\ ${ }^{3}$ Department of Animal Science, Universidad de las Palmas de Gran Canaria, 35413 Arucas, Spain. \\ 4 IFAPA Alameda del Obispo, 14071 Córdoba, Spain. \\ 5 Departamento de Agropecuária, CCHSA, Campus III, Universidade Federal da Paraíba, Bananeiras, Paraíba, Brazil.
}

\begin{abstract}
The aim of this research was to study the effects of three different management systems on growth and carcass quality of 61 Murciano-Granadina breed kids and their interaction with sex. In the extensive system, 21 kids were allocated to suckle from their dams on free-range pasture with no additional feedstuff. In the semi-intensive system, 20 kids were suckled from their dams and had access to alfalfa hay and cereal straw (no free-range pasture). In the intensive system, 20 kids were separated from the dams at birth and then fed with milk replacer and alfalfa hay. Animals were slaughtered at $7.00 \pm 1.00 \mathrm{~kg}$ of average BW. The semi-intensive system and extensive system kids grew faster than intensive system animals (127, 113 and $96 \mathrm{~g} / \mathrm{d}$, respectively). Differences in energy intake may explain these differences. Intensive system kids displayed the lowest real dressing percentages, calculated as $100 \times$ (hot carcass weight/empty body weight), due to high development of empty gastrointestinal tract. The long leg and carcass were larger in extensive system kids than in kids from other management systems, presumably due to high physical activity on the free-range pastures. The carcasses and cuts from semi-intensive system and extensive system kids displayed more fat than those of intensive system kids. Males grew faster than females (122 and $103 \mathrm{~g} / \mathrm{d}$, respectively). Carcasses in male kids showed a higher content of bones but a lower content of fat than carcasses in female kids. The extensive system is feasible for producing kid meat from a dairy breed.
\end{abstract}

Key Words: average daily gain, meat, Murciano-Granadina breed

\section{Introduction}

Although European goats are mostly used to produce milk and cheese, in Mediterranean countries goat meat is a profitable and important part of the income of breeders (Working Group FAO/CIHEAM, 2002), and some organizations value goat meat production from traditional production systems (Dubeuf et al., 2004). Although goat production in the United States has historically been a low-labor business with little emphasis on animal production and management practices, the meat-goat industry has recently grown (Cameron et al., 2001; Oman et al., 1999; Sahlu et al., 2009), providing new opportunities for additional income derived from diversified farming operations. This rising interest/demand for goat meat in the United States has possibly been a result of increased ethnic diversity. Worldwide pork and beef are mainly consumed in urban areas, but goat meat is mainly consumed in rural areas, and most meat is sold at local or regional markets for domestic consumption. However, goat meat is becoming increasingly popular because of its positive ecological image, dietetic and health benefits, the cultural tendency of consumers towards natural foods, recent food crises, and the association of goat meat with religious holidays (Dubeuf et al., 2004). The effect of the type of management system on the carcass quality of goats has been investigated in a limited number of studies. Extensive meat goats are fed on forages, increasing the profit to the producers; pasture based production systems are limited, however, because of seasonal variations in nutrient content of the pasture forage. This often means that the pasture by itself does not provide adequate nutrition for quickly growing animals (Wilkinson \& Stark, 1987). In intensive with artificial or natural rearing systems, an additional protein and energy source (hay or concentrate) is offered to maintain acceptable goat performance. Thus, the objectives of this study were to determine the effects of the different types of management systems and sex on growth and carcass quality in dairy goat kids. 


\section{Material and Methods}

The experiment started in January 2007 and took place in Granada, located at $37^{\circ} 11^{\prime}$ N latitude and $3^{\circ} 35^{\prime}$ W longitude, $570 \mathrm{~m}$ above the sea level and under mediterranean ecosystem.

Sixty-one Murciano-Granadina kids (28 females, 33 males) from the herd located in the Farm Research of Diputación de Granada in Albolote (Granada, Spain) at $37^{\circ} 14^{\prime}$ latitude and $-3^{\circ} 39^{\prime}$ loongitude, $655 \mathrm{~m}$ above mean sea level, were raised under 3 different management systems (extensive, semi-intensive, and intensive) all located in the Farm Research of Diputación de Granada. Animal handling was according to the guidelines of the EC Directive 86/609/ EEC (European Communities, 1986).

The 21 kids ( 9 females, 12 males) in the extensive system suckled directly from dams and were raised on a free-range pasture containing mostly wheat (Triticum Sativum Lam. T. Vulgare), oat (Avena sativa), and chickpeas (Cicer arietinum), with no additional feedstuff. At night, they were housed with their dams in a stable. Kids (9 females, 11 males) in the semi-intensive system suckled directly from dams and had access to alfalfa hay and cereal straw. The semi-intensive system kids did not have access to a pasture. The 20 kids (10 females, 10 males) in the intensive system were separated from dams after birth, housed in an artificial rearing room, and fed colostrum for the first 2 days, as described by Castro et al. (2005). Then, kids had free access to milk replacer $24 \mathrm{~h}$ a day (Univet lambs and kids 60, Nutral S.A., Madrid, Spain; $6.00 \%$ ash, $0.04 \%$ cellulose, $24.00 \%$ protein , and $24.50 \%$ fat on dry matter), which was sucked from a teat connected to a unit for feeding liquid dieta. This feeding regimen was supplemented with alfalfa hay. Kids from all 3 systems had free access to water at all times.

Kids were weighed at birth and then weekly until slaughter with a digital hook weight (PCE-HS 50, maximum $=50 \mathrm{~kg}$, e $=20$ g, PCE Group Ibérica, Albacete, Spain).

Kids were slaughtered at Los Filabres SCA when their body weight was $7.00 \pm 1.00 \mathrm{~kg}$. Kids were fasted with free access to water during the 24 hours before slaughter. The slaughter procedure and carcass definition were as described by Colomer-Rocher et al. (1987). Hot (after slaughter) and chilled (after $24 \mathrm{~h}$ chilling at $4{ }^{\circ} \mathrm{C}$ ) carcass weight (PCE-HS 50 , maximum $=50 \mathrm{~kg}, \mathrm{e}=20 \mathrm{~g}$, PCE Group Ibérica, Albacete, Spain) and weights of the head, skin, heart, liver, lungs and trachea, kidney, full and empty gastrointestinal tract (gastrointestinal content was determined as the difference between them), and spleen were recorded using electronic weights (G-310, maximum = 15 kg, e = 5 g, Dibal S.A., Bilbao, Spain; and Tefal model Gourmet, maximum $=5 \mathrm{~kg}, \mathrm{e}=1 \mathrm{~g}$,
Groupe SEB Ibérica, Barcelona, Spain). Empty body weight (EBW) was calculated by subtracting the weight of the gastrointestinal contents from fasted body weight (FBW). Dressing carcass percentages were calculated using chilled carcass weight (CCW), hot carcass weight (HCW), FBW, and EBW. The commercial and real dressing percentages (CDP and RDP respectively) were calculated as follows:

$$
\begin{aligned}
& \mathrm{CDP}=100 \times(\mathrm{CCW} / \mathrm{FBW}) \\
& \mathrm{RDP}=100 \times(\mathrm{HCW} / \mathrm{EBW})
\end{aligned}
$$

Carcass measurements included long leg length from the symphysis pubis to the tarsal-metatarsal joint (McMeekan, 1939); carcass length, from the symphysis pubis to the anterior edge of the middle of the first rib (Pálsson, 1939); maximum width, between femur trochanters (Pálsson, 1939); and maximum distance, between the sternum and the sixth thoracic vertebra (Pálsson, 1939).

After chilling, carcasses were split down. The left side was divided into five prime cuts (neck, flank, ribs, shoulder, and long leg) and three minor cuts (kidney, kidney fat, and tail), as described by Colomer-Rocher et al. (1987). Prime cuts were weighed (Tefal model Gourmet, maximum $=5 \mathrm{~kg}$, e = $1 \mathrm{~g}$, Groupe SEB Ibérica, Barcelona, Spain) and dissected into separable tissues (subcutaneous and intermuscular fat, lean, bone). The separable tissues were weighed with the same weight described above.

Two-way ANOVA analysis (SAS Institute Inc., 19992001, v. 8.2. for Windows, Cary, North Carolina, USA) was performed including the fixed effects management system and sex, and the interaction between them. Finally, a Duncan post-Hoc test (SAS Institute Inc., 1999-2001, v. 8.2. for Windows. Cary, North Carolina, USA) was used to determine in which factor level the differences were located.

\section{Results and Discussion}

The results of factorial ANOVA, including the fixed effect of the management system and the sex as well as their interaction, applied to the weight at birth and at 7, 14, 21, and 28 days old, and the ADG (average daily gain) from birth to slaughter, showed statistical differences between the management systems (Table 1). The results also showed that there were no significant differences between sexes in relation to growth.

Statistical differences between the three management systems were found for birth weight. Kids managed under semi-intensive ( $3.52 \mathrm{~kg}$ ) and intensive system (3.54 kg) were heavier at birth than kids managed under extensive system (3.05 kg). A better diet for the dams in the semi-intensive system and intensive system may explain these differences in birth weight. It has been demonstrated that the diet of 
Table 1 - Effect of management system and sex on estimated weights at different ages and average daily gain

\begin{tabular}{|c|c|c|c|c|c|c|}
\hline \multirow[t]{2}{*}{ Item } & \multicolumn{3}{|c|}{ Management system } & \multicolumn{2}{|c|}{ Sex } & \multirow[t]{2}{*}{ SEM } \\
\hline & Extensive & Semi-intensive & Intensive & Male & Female & \\
\hline Weight at birth, kg & $3.05 b$ & $3.52 \mathrm{a}$ & $3.54 \mathrm{a}$ & 3.71 & 3.13 & 0.11 \\
\hline at 14 days & $4.25 \mathrm{ab}$ & $4.37 \mathrm{a}$ & $3.95 b$ & 4.53 & 3.86 & 0.09 \\
\hline at 21 days & $5.08 \mathrm{~b}$ & $5.71 \mathrm{a}$ & $4.86 \mathrm{~b}$ & 5.77 & 4.87 & 0.14 \\
\hline $0-28$ days & $113.58 \mathrm{a}$ & $127.58 \mathrm{a}$ & $96.02 b$ & $122.26 \mathrm{a}$ & $103.53 b$ & 4.62 \\
\hline
\end{tabular}

Means followed by different letters on the same row differ $(\mathrm{P}<0.05)$ significantly. $\mathrm{SEM}=$ standard error of the mean.

pregnant females affects the birth weight of kids, and dams from the semi-intensive system and intensive system had free access to feedstuff (Tag-Eldin, 2000). Camacho et al. (2009) did not find statistical differences in birth weight for kids from Blanca Serrana Andaluza breed goats born in extensive or intensive system; however, this is a meatspecialized breed, and the animals were not milked. Thus, the Blanca Serrana Andaluza goats were able to accumulate fat reserves that did not result in differences in birth weight.

At 7, 21, and 28 days of age, semi-intensive system kids were heavier than intensive system and extensive system kids. At 14 days of age, semi-intensive system kids were heavier than intensive system kids. The intensive system kids displayed the lowest estimated weights at all ages tested. The intensive system kids received milk replacer as described in Material and Methods, and some authors (Argüello et al., 2004) have reported lower weight in kids fed milk replacer relative to goat milk due to low energy and protein intake.

Two possibilities can account for the statistical differences between semi-intensive system and extensive system estimated weights. As described in Material and Methods, extensive system animals went to the pasture daily with dams, which increased their maintenance requirements. It is well established that grazing animals expend more energy than animals in confinement (Lachica \& Aguilera, 2005), for two main reasons. First, in the stall, food is offered in a partially processed form, which makes it easier to ingest and digest. In addition, an animal in a stall does not have to move to search for food. Second, as Blaxter (1967) suggested, the high maintenance requirements of sheep in pastures may be due to an increased cost of body movement in the pasture, especially the cost of walking and harvesting herbage. On the other hand, milk quality and quantity can be affected by the nutritional status of the dam (MorandFehr, 2005). As extensive system goats did not receive any feed supplements, their milk quality and quantity were lower than in semi-intensive system goats, and thus, these kids showed a lower estimated weight at $28 \mathrm{~d}$. In addition, Johnson \& McGowan (1998) found statistical differences between young goats from a native Florida breed reared in intensive and semi-intensive systems. At the same age at slaughter, goats raised in an intensive system had heavier slaughter weights than goats raised in a semi-intensive system.

As shown by ADG, semi-intensive system and extensive system kids grew faster than intensive system kids. Although the measured ADG for semi-intensive system kids was $10.97 \%$ higher than for extensive system kids, this difference was not statistically significant due to the high coefficient of variation. Similarly to the explanation for estimated weights, semi-intensive system kids received more and better quality milk than extensive system kids due to supplementation of the dam's feedstuff and no energy expenditure to move to pasture (Blaxter, 1967; Lachica \& Aguilera, 2005; Morand-Fehr, 2005). The lower protein and energy intake by intensive system kids fed with milk replacer may be the reason why these kids had the lowest ADG. In contrast, Camacho et al. (2009) did not find statistical differences in daily gains with respect to their Blanca Serrana Andaluza goats reared under extensive or intensive management systems. The differences between the results of Camacho et al. (2009) and our current study may lie in the different breed types; the current study was performed using dairy goats, and the previous one focused on meat goats.

No statistical differences were observed between sexes at any tested age, although a trend towards heavier weights in males was observed. The kids in the current study were slaughtered at low FBW as is the usual practice in Spain. Thus, low FBW may explain the absence of statistical differences between sexes, in addition to the high standard error of the mean. Consistent with our observations, Argüello et al. (2004) did not find statistical differences between sexes in ADG in another dairy Spanish breed (Majorera breed) slaughtered at the same weight. Peña et al. (1994) did 
not find statistical differences by sex in Florida Sevillana dairy breed goats. In meat breeds, Camacho et al. (2009) and Costa et al. (2010) did not find statistical differences in ADG with respect to kid sex in Blanca Serrana Andaluza goats.

Male and female kids (Table 1) showed significant differences related to ADG. Males grew faster than females. In goat species, differences in ADG between males and females have sometimes been reported (Argüello et al., 2004) and sometimes they have not (Mavrogenis, 1983). Number of animals, breed effect, trial length, and many other factors may explain the controversial observations.

FBW (Table 2) was not statistically different between the three management systems, but extensive system kids tended to have a lower FBW than semi-intensive system and intensive system kids. Semi-intensive system and extensive system animals were slaughtered before intensive system kids because they need less time to weight 7.00 \pm $1.00 \mathrm{~kg}$. HCW ranged from 3.64 to $4.09 \mathrm{~kg}$, with semiintensive system kids being heavier than extensive system and intensive system kids. The weight loss by evaporation on carcasses is due to the effects of chilling averaged $4.10 \%$ for all groups, which is consistent with that reported by Argüello et al. (2007) with similar FBW. Similar results among management systems were observed for CCW. The differences in HCW and CCW between semi-intensive system and extensive system kids were due to the lower FBW observed in extensive system animals. The differences between semi-intensive system and intensive system kids were due to a greater contribution of the weight of the gastrointestinal tract to FBW in intensive system kids.

Semi-intensive system kids displayed the greatest CDP values. Full gastrointestinal tract and skin percentages of FBW were greater in intensive system kids, which reduced the CDP in these animals relative to semi-intensive system kids. Consistent with the observation by Argüello et al. (2007), at similar FBW, kids fed milk replacer showed greater gastrointestinal tract development than kids nursed by dams because they began to eat alfalfa hay earlier, as a consequence of the fact that milk replacer did not provide all nutritional requirements. Extensive system kids showed lower CDP than semi-intensive system kids because the head and full gastrointestinal tract percentages were greater in extensive system kids. Similarly, the RDP for semiintensive system kids was greater than for intensive system and extensive system kids. Because extensive system animals had greater gastrointestinal tract content, the RDP of these animals resulted in significantly greater values than intensive system kids. Zurita-Herrera (2007) found statistical differences in the CDP between Blanca Serrana Andaluza meat breed kids of the intensive system (47.76\%) and extensive system (45.35\%), but there were no statistical

Table 2 - Effects of management system and sex on fasted body weight, age at slaughter, carcass weight and dressing percentages, linear dimensions and prime cuts percentages

\begin{tabular}{|c|c|c|c|c|c|c|}
\hline \multirow[t]{2}{*}{ Item } & \multicolumn{3}{|c|}{ Management system } & \multicolumn{2}{|c|}{ Sex } & \multirow[t]{2}{*}{ SEM } \\
\hline & Extensive & Semi-intensive & Intensive & Male & Female & \\
\hline FBW, kg & 6.78 & 7.40 & 7.11 & 7.19 & 6.98 & 0.09 \\
\hline Age at slaughter, days & $33.87 \mathrm{a}$ & $33.76 \mathrm{a}$ & $38.37 b$ & $35.09 a$ & $46.18 b$ & 1.09 \\
\hline \multicolumn{7}{|l|}{ Carcass weights } \\
\hline Hot carcass wt, kg & $3.64 b$ & $4.09 \mathrm{a}$ & $3.72 b$ & 3.86 & 3.76 & 0.05 \\
\hline Cold carcass wt, kg & $3.47 \mathrm{~b}$ & $3.92 \mathrm{a}$ & $3.59 b$ & 3.72 & 3.59 & 0.05 \\
\hline \multicolumn{7}{|c|}{ Carcass dressing percentages } \\
\hline Commercial dressing \% & $51.00 \mathrm{~b}$ & $52.87 \mathrm{a}$ & $50.98 b$ & 51.70 & 51.45 & 0.24 \\
\hline Real dressing \% & $56.10 \mathrm{~b}$ & $57.34 \mathrm{a}$ & $55.27 c$ & 56.29 & 56.31 & 0.23 \\
\hline \multicolumn{7}{|l|}{ Linear dimensions } \\
\hline Long leg length, cm & $25.75 b$ & $23.91 \mathrm{a}$ & $23.85 a$ & 24.91 & 24.07 & 0.18 \\
\hline Carcass length, cm & $41.01 b$ & $38.96 a$ & $40.59 b$ & 40.02 & 40.42 & 0.24 \\
\hline $\mathrm{G}^{1}, \mathrm{~cm}$ & $9.24 \mathrm{a}$ & $9.44 \mathrm{a}$ & $8.87 b$ & 9.10 & 9.29 & 0.07 \\
\hline $\mathrm{Th}^{2}, \mathrm{~cm}$ & 15.21 & 14.94 & 14.96 & 15.07 & 15.01 & 0.08 \\
\hline \multicolumn{7}{|l|}{ Prime cut percentages } \\
\hline Shoulder & $17.38 b$ & $16.18 \mathrm{a}$ & $16.78 \mathrm{ab}$ & 16.92 & 16.64 & 0.10 \\
\hline Leg & 22.39 & 21.98 & 22.69 & 22.04 & 22.72 & 0.14 \\
\hline Ribs & $28.04 b$ & $31.90 \mathrm{a}$ & $29.86 c$ & 29.99 & 29.81 & 0.29 \\
\hline All cuts & $67.81 \mathrm{~b}$ & $70.06 a$ & 69.33ab & 68.95 & 69.16 & 0.40 \\
\hline
\end{tabular}

Means followed by different letters on the same row differ significantly $(\mathrm{P}<0.05)$.

${ }^{1}$ Maximum width between femur trochanters.

2 Maximum distance between sternum and sixth thoracic vertebra.

$\mathrm{SEM}=$ standard error of the mean. 
differences in the RDP. Those results are opposite to the ones observed in present study, but differences in breed aptitude may explain this controversy.

Extensive system kids had the greatest long leg length (Table 2), and no significant differences were observed between semi-intensive system and intensive system animals. Animals raised in small pens have a shorter long leg length (Borghese et al. 1990); in the present study, extensive system kids moved to the pasture daily, and thus would be expected to have a greater long leg length. Semi-intensive system kids showed the shortest carcass, but no significant differences were observed between extensive system and intensive system animals. These results may be because extensive system animals moved to the pasture daily, and intensive system animals were the oldest. Extensive system kids and semi-intensive system kids had the greatest maximum width between femur trochanters. No statistical differences between the management systems were observed for the maximum distance between sternum and sixth thoracic vertebra. Similar results were reported by Zurita-Herrera (2007) using Blanca Serrana Andaluza meat breed, in which statistical differences were found in the carcass length between the extensive system $(54.10 \mathrm{~cm})$ and intensive system $(52.20 \mathrm{~cm})$. Some authors have reported that carcasses become more compact with increased age at slaughter (Anous \& Mourad, 2001; Attah et al., 2004; Marichal et al., 2003; Mourad et al., 2001).

For prime cut percentages (Table 2), the shoulder percentage of HCW was the lowest in the semi-intensive system group. Although statistical differences were observed between semi-intensive system and extensive or intensive system kids, these results were not biologically relevant.
There was no effect of management system on long leg percentage of HCW. Ribs in semi-intensive system kids significantly contributed to HCW more than ribs in extensive system or intensive system kids. There were no differences between extensive system and intensive system kids with respect to the contribution of ribs to HCW. In agreement with our results, Zurita-Herrera (2007) showed that meat breed kids from an intensive system had a greater percentage of ribs (25.00\%) than kids from an extensive system (22.50\%). The contribution of the high value cuts of semi-intensive system kids to HCW was significantly greater than that in extensive system or intensive system animals.

The sex effects (Table 2) were only significant for age at slaughter because the FBW was fixed and the ADG for females was lower than in males. Similar findings were reported by Zurita-Herrera (2007) using Blanca Serrana Andaluza meat goats.

No significant differences were observed between management systems in blood, fore and hind feet, head, full gastrointestinal tract, gastrointestinal content, liver, urinary bladder, male genitals, spleen, right kidney, lungs and trachea, heart, and swindle (Table 3). Intensive system kids were reared indoors with no bedstraw, unlike semi-intensive system and extensive system animals. These management differences may explain the significantly greater skin percentage observed in intensive system animals because the absence of bedstraw caused a greater skin development as a way to protect themselves from low temperatures. As described by Argüello et al. (2007), intensive system kids displayed the greatest percentage of empty gastrointestinal tract due to their starting to feed on alfalfa hay sooner than the others.

Table 3 - Effects of management system and sex on different noncarcass components (as a percentage of fasted body weight)

\begin{tabular}{|c|c|c|c|c|c|c|}
\hline \multirow[b]{2}{*}{ Item, \% } & \multicolumn{3}{|c|}{ Management system } & \multicolumn{2}{|c|}{ Sex } & \multirow[b]{2}{*}{ SEM } \\
\hline & Extensive & Semi-intensive & Intensive & Male & Female & \\
\hline Blood & 4.40 & 3.92 & 3.67 & 5.18 & 4.86 & 0.23 \\
\hline Skin & $8.48 \mathrm{a}$ & $8.54 a$ & $9.38 b$ & 8.88 & 8.69 & 0.09 \\
\hline Fore and hind feet & 4.21 & 4.26 & 4.79 & 4.63 & 4.17 & 0.07 \\
\hline Head & 7.47 & 7.25 & 7.95 & 7.50 & 7.62 & 0.14 \\
\hline Full gastrointestinal tract & 13.30 & 13.09 & 14.80 & 13.13 & 14.42 & 0.25 \\
\hline Gastrointestinal tract content & 4.45 & 3.66 & 3.86 & 3.86 & 4.63 & 0.18 \\
\hline Empty gastrointestinal tract & $8.84 \mathrm{a}$ & $9.43 \mathrm{ab}$ & $10.28 b$ & 9.27 & 9.79 & 0.15 \\
\hline Liver & 2.32 & 2.47 & 2.77 & 2.50 & 2.54 & 0.04 \\
\hline Urinary bladder & 0.23 & 0.19 & 0.26 & 0.24 & 0.21 & 0.02 \\
\hline Masculine genitals & 0.36 & 0.16 & 0.24 & 0.26 & - & 0.01 \\
\hline Spleen & 0.28 & 0.26 & 0.24 & 0.26 & 0.26 & 0.01 \\
\hline Right kidney & 0.53 & 0.50 & 0.50 & 0.52 & 0.50 & 0.01 \\
\hline Lungs and trachea & 2.49 & 2.03 & 2.36 & 2.33 & 2.26 & 0.05 \\
\hline Heart & 0.68 & 0.74 & 0.65 & 0.70 & 0.68 & 0.01 \\
\hline Swindle & 0.25 & 0.19 & 0.28 & 0.27 & 0.21 & 0.02 \\
\hline
\end{tabular}

Means followed by different letters In the same row differ significantly $(\mathrm{P}<0.05)$.

SEM = standard error of the mean. 
For half-carcass fat deposits (Table 4), the subcutaneous fat percentages of semi-intensive system and extensive system kids were significantly greater than in intensive system kids. For half-carcass intermuscular fat, the semi-intensive system percentage was the greatest. The contribution of fat to joint weight of ribs and flanks was statistically significant. Thus, semi-intensive system kids showed a significantly greater fat contribution than extensive system or intensive system animals. The low subcutaneous fat percentages in intensive system kids may be due to the relatively low energy intake by goat kids fed milk replacer (Argüello et al., 2007; Morand-Fehr et al., 1986). Zurita-Herrera (2007) reported a greater percentage of perirrenal and pelvic fat in Blanca Serrana Andaluza meat goat kids reared in an intensive system (3.46\%) than kids reared in an extensive system (1.11\%). Other researchers have noted that goats fed a complete concentrate ration exhibit increased carcass fat deposition, compared with browsing or grazing animals (Ash \& Norton, 1987;
McGregor, 1985). Joy et al. (2008) demonstrated that intermuscular fat deposits were lower in lambs pastured continuously than in lambs housed indoors, which is in agreement with our findings in extensive system kids that moved to the pasture daily.

Intermuscular and subcutaneous fat percentages on half carcasses or cuts were similar to those described for other dairy breed goats (Argüello et al., 2007). Bone halfcarcass and cut percentages were not affected by the type of management system because the wave of bone development had been completed (Hammond, 1966). Bone percentages in half carcasses and cuts were not affected by the type of management system, and the results were according to other dairy breeds kids (Argüello et al., 2007). In contrast to bone percentage, lean percentages were affected by the management system in half carcasses, long legs, ribs, and flank cuts (Table 4). Intensive system kids displayed the greatest lean half-carcass percentage. Long legs and rib cuts showed lower lean percentages in semi-

Table 4 - Effects of management system and sex on half-carcass and prime cuts' composition

\begin{tabular}{|c|c|c|c|c|c|c|}
\hline \multirow[b]{2}{*}{ Item, \% } & \multicolumn{3}{|c|}{ Management system } & \multicolumn{2}{|c|}{ Sex } & \multirow[b]{2}{*}{ SEM } \\
\hline & Extensive & Semi-intensive & Intensive & Male & Female & \\
\hline \multicolumn{7}{|l|}{ Total half-carcass } \\
\hline Intermuscular fat & $1.74 \mathrm{~b}$ & $3.45 \mathrm{a}$ & $2.21 b$ & 2.30 & 2.92 & 0.15 \\
\hline Bone & 32.48 & 31.59 & 31.31 & $32.56 a$ & $30.92 b$ & 0.28 \\
\hline Lean & $55.89 \mathrm{~b}$ & $54.07 \mathrm{a}$ & $57.38 c$ & $55.25 a$ & 56.40 & 0.33 \\
\hline Intermuscular fat & 0.56 & 0.83 & 0.59 & 0.57 & 0.77 & 0.06 \\
\hline Bone & 35.40 & 35.96 & 34.45 & 35.61 & 34.87 & 0.36 \\
\hline Lean & 55.21 & 54.34 & 55.77 & 54.59 & 55.71 & 0.29 \\
\hline \multicolumn{7}{|l|}{ Long leg } \\
\hline Subcutaneous fat & $3.81 \mathrm{a}$ & $3.45 \mathrm{a}$ & $1.95 \mathrm{~b}$ & 2.84 & 3.37 & 0.21 \\
\hline Subcutaneous fat & $2.38 \mathrm{~b}$ & $3.51 \mathrm{a}$ & $1.67 \mathrm{~b}$ & 2.40 & 2.65 & 0.23 \\
\hline Intermuscular fat & $2.81 \mathrm{~b}$ & $5.25 \mathrm{a}$ & $3.30 \mathrm{~b}$ & 3.49 & 4.13 & 0.23 \\
\hline Bone & 35.05 & 31.87 & 32.46 & 34.46 & 31.62 & 0.45 \\
\hline Lean & $49.74 a$ & $48.02 \mathrm{a}$ & $52.00 \mathrm{~b}$ & 49.21 & 50.75 & 0.43 \\
\hline \multicolumn{7}{|l|}{ Neck } \\
\hline Subcutaneous fat & 1.23 & 2.55 & 0.80 & 1.36 & 1.72 & 0.34 \\
\hline Intermuscular fat & 2.76 & 3.53 & 2.59 & 3.05 & 2.85 & 0.28 \\
\hline Bone & 29.73 & 29.70 & 30.77 & 30.40 & 29.66 & 0.62 \\
\hline Lean & 56.85 & 54.73 & 55.47 & 55.45 & 56.01 & 0.84 \\
\hline \multicolumn{7}{|l|}{ Flank } \\
\hline Subcutaneous fat & $7.22 \mathrm{a}$ & $7.70 \mathrm{a}$ & $3.37 b$ & 6.68 & 5.45 & 0.50 \\
\hline
\end{tabular}

Means followed by different letters on the same row differ significantly $(\mathrm{P}<0.05)$.

$\mathrm{SEM}=$ standard error of the mean. 
intensive system and extensive system kids than in intensive system kids. Similar to the previously mentioned cuts, semi-intensive system kids presented the lowest lean percentage in flanks. The lean percentage in shoulder and neck was not affected by the type of management system. Tissue composition was expressed as the percentage of each tissue of the total cut weight. Thus, intensive system kids displayed low fat levels in the carcass, increasing the lean percentages. Similar results in dairy breeds have been reported by Argüello et al. (2007). In addition to the previous explanation, Atti et al. (2004) observed comparable bone carcass percentages when CP intake increased, but, conversely, the proportions of fat and muscle were affected by the CP intake level. Kids in Atti et al. (2004)'s study fed a medium protein diet had relatively more muscle and lower fat than those receiving a high protein-content diet.

Female half carcasses were fatty (no significant effect), less bony, and leaner than males. Significant differences were observed in the bone percentage of the long leg, in which males were bonier than females. Some researchers have reported that female goat carcasses have a greater fat percentage than either castrated or intact males (ColomerRocher et al., 1992; Hogg et al., 1992; Warmington \& Kirton, 1990). Zurita-Herrera (2007) found that female Blanca Serrana Andaluza meat breed goats accumulated more total fat than males.

\section{Conclusions}

Extensive system represents a realistic possibility to produce kid meat from a dairy breed. Further studies must assess the economic feasibility and meat quality of kids reared under extensive system management. Although semi-intensive and extensive systems produced some minimal differences in carcass quality, the carcasses produced by semi-intensive and extensive systems were quite similar. The use of intensive system for kid carcass production when pastures are available is recommended if milk is to be transformed into cheese with high value added. Differences between males and females were only found for growth and tissue composition, which suggests that farmers can rear males and females together with no expected differences in carcass quality.

\section{Acknowledgements}

The authors thank Diputación de Granada, MurcianoGranadina National Breeders Association and Los Filabres SCA for the financial support for this study.

\section{References}

ANOUS, M.R.; MOURAD, M. Technical note: Some carcass characteristics of Alpine kids under intensive versus semiintensive systems of production in France. Small Ruminant Research, v.40, p.193-196, 2001.

ARGÜELLO, A.; CASTRO, N.; CAPOTE, J. Growth of milk replacer kids fed under three different managements. Journal of Applied Animal Research, v.25, p.37-40, 2004.

ARGÜELlO, A.; CASTRO, N.; CAPOTE, J. et al. The influence of artificial rearing and live weight at slaughter on kid carcass characteristics. Journal of Animal and Veterinary Advances, v.6, n.1, p.20-25, 2007.

ASH, A.J.; NORTON, B.W. Studies with the Australian cashmere goat. II. Effects of dietary protein concentration and feeding level on body composition of male and female goats. Australian Journal of Agricultural Research, v.38, p.971-982, 1987.

ATTAH, S.; OKUBANJO, A.O.; OMOJOLA, A.B. et al. Body and carcass linear measurements of goats slaughtered at different weights. Livestock Research for Rural Development, v.16, n.8, 2004 (Paper 62).

ATTI, N.; ROUISSI, H.; MAHOUACHI, M. The effect of dietary crude protein level on growth, carcass and meat composition of male goat kids in Tunisia. Small Ruminant Research, v.54, p.89-97, 2004.

BLAXTER, K.L. The energy metabolism of ruminants. London: Hutchinson, 1967. 259p.

BORGHESE, A.; TERZANO, G.M.; BARTOCCI, S. La produzione del capretto negli allevamenti intensiva. 6. Caratteristiche della carcassa e della carne in soggetti Saanen e Camosciata delle Alpi di 35 e 50 giorni di eta. Zootecnia e Nutrizione Animale, v.16, p.167-178, 1990.

CAMACHO, M.E.; COSTA, R.G.; VALLECILLO, A.F. et al. Short note: An experimental approach to the standardized weight and daily gain of the Blanca Andaluza kids. Tropical and Subtropical Agroecosystems, v.11, p.101-104, 2009.

CAMERON, M.R.; LUO, J.; SAHLU, T. et al. Growth and slaughter traits of Boer x Spanish, Boer x Angora, and Spanish goats consuming a concentrate-based diet. Journal of Animal Science, v.79, p.1423-1430, 2001.

CAStRo, N.; CAPOTE, J.; ÁlVAREZ, S. et al. Effects of lyophilized colostrums feeding regimens on passive transfer of immunoglobulin G in Majorera goat kids. Journal of Dairy Science, v.88, n.10, p.3650-3654, 2005.

COLOMER-ROCHER, F.; MORAND-FEHR, P.; KIRTON, A.H. Standard methods and procedures for goat carcass evaluation, jointing and tissue separation. Livestock Production Science, v.17, p.149-159, 1987

COLOMER-ROCHER, F.; KIRTON, A.H.; MERCER, G.J.K. et al. Carcass composition of New Zealand Saanen goats slaughtered at different weights. Small Ruminant Research, v.7, p.161-173, 1992.

COSTA, R.G.; CAMACHO, M.E.; DELGADO, J.V. et al. Influência do sexo do animal e do sistema de produção nas características de carcaça de caprinos da raça Blanca Serrana Andaluza. Revista Brasileira de Zootecnia, v.39, n.2, p.382-386, 2010.

DUBEUF, J.P.; MORAND-FEHR, P.; RUBINO, R. Situation, changes and future of goat industry around the world. Small Ruminant Research, v.51, p.165-173, 2004.

EUROPEAN COMMUNITIES. Council directive of 24 November 1986 on the approximation of laws, regulations and administrative provisions of the Member States regarding the protection of animals used for experimental and other scientific purposes (86/609/EEC).

HAMMOND, J. Principios de la explotación animal. Zaragoza: Acribia, 1966. 363p.

HOGG, B.W.; MERCER, G.J.K.; MORTINER, B.J. et al. Carcass and meat quality attributes of commercial goats in New Zealand. Small Ruminant Research, v.8, p.243-256, 1992. 
JOHNSON, D.D.; MCGOWAN, C.H. Diet/management effects on carcass attributes and meat quality of young goats. Small Ruminant Research, v.28, p.93-98, 1998.

JOY, M.; RIPOLL, G.; DELFA, R. Effects of feeding system on carcass and non-carcass composition of Churra Tensina light lambs. Small Ruminant Research, v.78, p.123-133, 2008.

LACHICA, M.; AGUILERA, J.F. Energy expenditure of walk in grassland for small ruminants. Small Ruminant Research, v.59, p.105-121, 2005.

MARICHAL, A.; CASTRO, N.; CAPOTE, J. et al. Effects of live weight at slaugther $(6,10$ and $25 \mathrm{~kg}$ ) on kid carcass and meat quality. Livestock Production Science, v.83, p.247-256, 2003.

MAVROGENIS, A.P. Adjustment factors for growth characters of the Damascus goat. Livestock Production Science, v.10, p.479-486, 1983.

MCGREGOR, B.A. Growth, development and carcass composition of goats: a review. In: COPLAND, J. (Ed.) Goat production and research in the tropics. Brisbane, 1985. p.82-90.

MCMEEKAN, C.P. The Cambridge block test for fat lamb. In: ANNUAL MEETING OF SHEEP FARMERS, 8., 1939, Cambridge. Proceedings... Cambridge: 1939. p.52-57.

MORAND-FEHR, P.; BAS, P.; SCHMIDELY, P. et al. Facteurs influençant la qualité des carcasses de chevraux et en particulier son état d'engraissement (Factors influencing kid's carcass quality and particulary fattening score). In: JOURNÉES DE LA RECHERCHE OVINE ET CAPRINE, 11., 1986, Paris. Papers... Paris: 1986. p.236-252.

MORAND-FEHR, P. Recent developments in goat nutrition and application: a review. Small Ruminant Research, v.60, p.25-43, 2005.

MOURAD, M.; GBANAMOU, G.; BALDE, I.B. Carcass characteristics of West African dwarf goats under extensive system. Small Ruminant Research, v.42, p.83-86, 2001.

OMAN, J.S.; WALDRON, D.F.; GRIFFIN, D.B. et al. Effect of breed-type and feeding on goat carcass traits. Journal of Animal Science, v.77, p.3215-3218, 1999.
PÁLSSON, H. Meat qualities in the sheep with specialreference to Scottish breeds and crosses. I. Carcass measurements and "sample joints" as indice of quality and composition. Journal of Agricultural Science, v.29, p.544-625,1939.

PEÑA, F.; GUTIÉRREZ, M.J.; HERRERA, M. et al. Crecimiento postnatal y rendimientos canal en cabritos de raza Florida Sevillana. Archivos de Zootecnia, v.43, p.81-91, 1994.

SAHLU, T.; DAWSON, L.J.; GIPSON, T.A. et al. ASAS centennial paper: impact of animal science research on United States goat production and predictions for the future. Journal of Animal Science, v.87, p.400-418, 2009.

STATISTICAL ANALYSIS SYSTEM - SAS. User's guide. Version 8.2 Cary: SAS Institute, 1999-2001.

TAG-ELDIN, M.I. Studies on some productive and reproductive parameters of Nubian goats and their Saanen crossbreds under local environmental conditions. 2000. 357f. Thesis (PhD in Animal and Poultry Production) - Khartoum University, Khartoum.

WARMINGTON, B.G.; KIRTON, A.H. Genetic and non-genetic influences on growth and carcass traits of goats. Small Ruminant Research, v.3, p.147-165, 1990.

WILKINSON, J.M.; STARK, B.A. The nutrition of goats. In: HARESINE, W.; COLE, D.J.A. (Eds.) Recent advances in animal nutrition. London: Butterworths, 1987. p.91-106.

WORKING GROUP FAO/CIHEAM. The monitoring body on sheep and goat production systems in the Mediterranean: key figures and indicators of functioning and evolution. In: DUBEUF, J.P. (Ed.) Options Méditerranéennes, Etudes et Recherches CIHEAM-IAMZ. Zaragoza: J. P. DUBEUF, 2002. v.39, p.25-31.

ZURITA-HERRERA, P. Estudio de las características de la canal de los cabritos de raza Blanca Serrana Andaluza. 2007. 195f. Thesis (Master in Animal Production) - Córdoba University, Córdoba. 